\title{
PIGEON PEA PROTEIN CONCENTRATE (CAJANUS CAJAN) SEEDS GROWN IN ECUADOR FUNCTIONAL PROPERTIES
}

\author{
PAZMIÑO A ${ }^{1}$, VÁSQUEZ G ${ }^{1}$, CARRILLO $\mathbf{W}^{2,3 *}$ \\ ${ }^{1}$ Faculty of Mechanical Engineering and Production Sciences, ESPOL Polytechnic University, Campus Gustavo Galindo Km 30.5 Vía \\ Perimetral, Guayaquil, Ecuador. ${ }^{2}$ Laboratory of Functional Foods, Faculty of Foods Science and Engineering, Technical University of \\ Ambato, Campus Huachi, Ambato, Ecuador. ${ }^{3}$ Research Department, Faculty of Health and Human Sciences, Bolívar State University, Gabriel \\ Secaira, Guaranda, Ecuador. Email: wi.carrillo@uta.edu.ec
}

Received: 29 January 2018, Revised and Accepted: 27 March 2018

\section{ABSTRACT}

Objective: The aim of this study was to obtain pigeon pea protein concentrate (PC) of green seeds and mature seeds from Cajanus cajan grown in Ecuador and evaluate their functional properties.

Methods: Pigeon PC of green seeds (GPPPC) and pigeon PC of mature seeds (MPPPC) were obtained by alkaline extraction (pH 8.5) using the isoelectric precipitation at $\mathrm{pH} 4.5$ method. Content of protein was determined using the Dumas method. Functional properties were evaluated with the following functional properties: Protein solubility (PS), water absorption capacity (WAC), oil absorption capacity (OAC), emulsifying activity index (EAI), emulsion stability index (ESI), foaming capacity (FC), and foam stability (FS).

Results: GPPPC and MPPPC are statistical different $(\mathrm{p}<0.05)$ in the evaluation of functional properties such as WAC, OAC, EAI, ESI, FC, and FS. GPPPC and MPPPC have different PS profiles. GPPPC is higher in WAC and EAI; MPPPC is higher in OAC, EAI, FC, and FS properties.

Conclusions: PPPC can be used as functional ingredients that provide technological improvements in the generation of new food products. Both seed, green or mature, can be considered to obtain PPPC. The green or mature PPPC to be used would depend on the technological property required in the specific process for the food industry.

Keywords: Pigeon pea protein concentrate, Cajanus cajan, Extraction alkaline, Functional properties.

(c) 2018 The Authors. Published by Innovare Academic Sciences Pvt Ltd. This is an open access article under the CC BY license (http://creativecommons. org/licenses/by/4. 0/) DOI: http://dx.doi.org/10.22159/ajpcr.2018.v11i6.24966

\section{INTRODUCTION}

Protein concentrates (PC) or protein isolates (PI) are usually obtained from soybeans and milk proteins [1,2]. PC and PI are used as an ingredient to increase nutritional value and to provide favorable sensorial characteristics in food products [3,4]. The current problems of food security and malnutrition, together with the increase in population, high cost of animalbased food, globalized migration, restrictions due to allergies, and dietary preferences, have urged the identification and incorporation of new protein sources to enrich traditional formulations and diversify consumer products. Legumes are good candidates for this propose, with a high protein content and a low production cost $[5,6]$. Extraction alkaline followed by isoelectric precipitation is the methods mostly used to isolate proteins from animal and vegetable protein sources such as milk, soybean, amaranth, quinoa, sesame, sacha inchi, macadamia, and pigeon pea seeds. These technological processes can help to eliminate antinutritional factors [7-17].

Pigeon pea (Cajanus cajan) is a legume that belongs to the Fabaceae family, cultivated in countries of Asia, Africa, the Caribbean, and South America (Ecuador, Colombia, Venezuela, Peru, and Bolivia). Pigeon pea is used to improve the quality of the soil, for fodder or green manure, traditional medicine, and for human nutrition for their high nutritive value and biological properties. Pigeon pea is a rich source of protein and provides a good amount of starch, fiber, and minerals $[18,19]$.

Content of proteins of pigeon pea seeds can vary from $18 \%$ to $22 \%$ of total content. Pigeon pea seeds' main storage proteins are globulin proteins [20]. Pigeon pea proteins have a high content of essential amino acids such as lysine, valine, threonine, and phenylalanine. However, these seeds are generally deficient in sulfur amino acids such as cysteines and methionine [21].
Mwasaru et al. reported pigeon pea PI obtained by alkaline extraction at $\mathrm{pH} 8.5$ and pH 12.5 with a protein content of $83.4 \%$ and $78.1 \%$ of total content, respectively [22]. Butt and Batool reported pigeon pea PI obtained by alkaline extraction at $\mathrm{pH} 9.5$, with a protein content of $82.95 \%$ of total content [5]

Food ingredient applications of vegetable protein depend on proteins functional properties. Functional properties can affect the food behavior during manufacturing, processing, storage, preparation, and consumption, for the physical and chemical properties and the molecular structure and size of the proteins used. Most important functional properties of protein include solubility, water and oil absorptions, emulsification, foaming properties, and gelation. It is known that the variation in the protein content and functional properties is affected by the type of raw material (for example, green and mature seeds), the processing history of the obtained raw material, and finally the protein extraction method [23].

The aim of this study was to obtain Pigeon PC of green seeds (GPPPC) and pigeon PC of mature seeds (MPPPC) from pigeon pea (C. cajan) seeds and evaluate their functional properties.

\section{METHODS}

Green and mature pigeon pea seeds were acquired in the super market in Bolivar, Province of Manabí, Ecuador. Within the reproductive status scale, immature or green pigeon pea seeds were obtained at the end of the grain filling stage, while mature pigeon pea seeds were obtained at the end of their maturation stage. To obtain Green Pigeon Pea Flour, the green seeds free of damaged grains and foreign materials were scalded for $1.5 \mathrm{~min}$ and then dried at $50^{\circ} \mathrm{C}$ for $72 \mathrm{~h}$, and to obtain mature pigeon 
pea flour, mature seeds were dried at $50^{\circ} \mathrm{C}$ for $24 \mathrm{~h}$. Flours were milled (212 $\mu \mathrm{m}$ size) before protein extraction.

\section{Determination protein content, moisture, and ash in GPPPC and} MPPPC

The contents of moisture, protein, and ash in the samples of GPPPC and MPPPC from $C$. cajan seeds were determined using the standard methods described in the AOAC [24]. The samples protein content was determined by the micro-Kjeldahl method (AACC, 2000) using a protein-nitrogen coefficient of $\mathrm{N} \times 6.25$ [25]. The calculated contents were expressed on a dry weight basis. Each analysis was carried out in triplicate $(n=3)$, and data were reported as means \pm standard deviation (SD)

\section{Preparation of pigeon pea PC (PPPC)}

PPPCs were obtained using the alkaline method followed by the isoelectric precipitation method. For both, green and mature, pigeon pea flour, protein extraction was performed with a solution 1:10 (flour: water, w/v) adjusted to $\mathrm{pH} 8.5$ with $1 \mathrm{~N} \mathrm{NaOH}$. The suspension was stirred at $500 \mathrm{rpm}$ for $2 \mathrm{~h}$ and then centrifuged at $10,000 \mathrm{rpm}$ for $15 \mathrm{~min}$. The protein in the supernatant is precipitated by adjusting the $\mathrm{pH}$ to 4.5 using $1 \mathrm{~N} \mathrm{HCl}$. The precipitated protein was recovered by centrifugation at $10,000 \mathrm{rpm}$ for $15 \mathrm{~min}$. The protein extract was neutralized with $0.1 \mathrm{M} \mathrm{NaOH}$, lyophilized, and kept at $-20^{\circ} \mathrm{C}$ until further analysis. The protein content was determined by the Dumas method [26].

\section{Sodium dodecyl sulfate polyacrylamide gel electrophoresis (SDS- PAGE) electrophoresis}

GPPPC and MPPPC were evaluated with the SDS-PAGE electrophoresis technique. Samples ( $1 \mathrm{mg}$ sample/mL) were dissolved in a sample buffer composed by Tris- $\mathrm{HCl}(0.05 \mathrm{M}, \mathrm{pH} 6.8)$, SDS (1.6\%, w: v), glycerol $(8 \%, v: v), 2-m e r c a p t o e t h a n o l ~(2 \%, v: v)$, and bromophenol blue indicator $(0.002 \%, \mathrm{w}: \mathrm{v})$ and heated at $95^{\circ} \mathrm{C}$ for $5 \mathrm{~min}$. They were loaded into $12 \%$ bis-tris polyacrilamide gels. Electrophoretic separation was carried out at $200 \mathrm{~V}$ for $30 \mathrm{~min}$, using the XT MES running buffer (BioRad, Hercules, CA, USA) in the Mini-Protean electrophoresis system (Bio-Rad, CA, USA). The molecular weight (MW) marker (Precision Plus Protein TM Unstained standard, Bio-Rad) containing ten Strep-tagged recombinant proteins $(10 \mathrm{kDa}-250 \mathrm{kDa})$ was used. Gels were stained with Instant Coomassie Blue G-250 (Bio-Rad, Hercules, CA, USA) [27]

\section{Reverse-phase ultra-performance liquid chromatography (RP-} UHPLC) analysis of GPPPC and MPPPC

Characterization was also carried out by RP-UHPLC using an Agilent 1200 infinity series UHPLC system (Agilent Technologies, Waldbronn, Germany). The wavelength detector was $280 \mathrm{~nm}$. The column used was Zorbax EC C18 (Agilent Poroshell 120, $4.6 \mathrm{~mm} \times 50 \mathrm{~mm} \times 2.7 \mu \mathrm{m}$ of particle size). Samples were eluted at $1.0 \mathrm{~mL} / \mathrm{min}$ with a lineal gradient from $0 \%$ to $70 \%$ of solvent B (acetonitrile and trifluoroacetic acid, TFA, $0.270 \% \mathrm{v} / \mathrm{v}$ ) in solvent A (water and TFA, $0.370 \% \mathrm{v} / \mathrm{v}$ ) [28]

\section{Functional properties of the PPPC}

\section{Protein solubility (PS)}

PS was analyzed according to the method of Jarpa-Parra et al. [29] with slight modifications. PPPC was dissolved in distilled water at a concentration of $0.2 \%(\mathrm{w} / \mathrm{v})$, and the $\mathrm{pH}$ of the suspension was adjusted to $\mathrm{pH} 2.0-\mathrm{pH} 10.0$ using solutions $0.001 \mathrm{~N} \mathrm{HCl}$ and $\mathrm{NaOH}$. The suspensions were shaken for $1 \mathrm{~h}$ and centrifuged at 10,000 rpm for $10 \mathrm{~min}$ in a Sorvall Legend Micro 17 centrifuge (Thermo Fisher Scientific, Germany). The content of protein in the supernatant was analyzed with the BCA protein assay kit (Thermo Fisher Scientific, Germany) with bovine serum albumin as a standard protein. The content of soluble protein was expressed as the percentage of the content of protein present in the sample.

\section{Water absorption capacity (WAC)}

GPPPC or MPPPC was dissolved in distilled water at 1:10 ratio in a preweighed tube. The mixture was homogenized for $30 \mathrm{~s}$ every $10 \mathrm{~min}$ for 5 times. Then, the mixture was centrifuged at $\times 4,000 \mathrm{~g}$ for $20 \mathrm{~min}$ with Sorvall Legend Micro 17 centrifuge (Thermo Fisher Scientific,
Germany). The tubes were drained at $45^{\circ}$ angle for 10 min and then weighed. WAC was calculated as the content of water absorbed by the weight of the protein sample.

\section{Oil absorption capacity (OAC)}

GPPPC or MPPPC was dissolved in canola oil at 1:10 ratio in a preweighed tube. The mixture was homogenized for 1 min using a vortex and then every $5 \mathrm{~min}$ until $30 \mathrm{~min}$. Then, the mixture was centrifuged at $\times 2,000 \mathrm{~g}$ for $15 \mathrm{~min}$ with Sorvall Legend Micro 17 centrifuge (Thermo Fisher Scientific, Germany). Then, the oil is drained, and the tube is tilted for $10 \mathrm{~min}$ and then weighed. The result was expressed as the content of oil absorbed per gram of sample.

\section{Emulsifying properties}

Emulsifying activity index (EAI) and the emulsifying stability index (ESI) were determined by the turbidimetric method of Pearce and Kinsella [30] 1\% GPPPC.

$1 \%$ MPPPC solution in water was prepared and $\mathrm{pH}$ was adjusted to $\mathrm{pH} 7$. The solution was stirred for $1 \mathrm{~h}$. The emulsion was obtained by mixing $3 \mathrm{~mL}$ of protein solution with $1 \mathrm{~mL}$ of canola oil with an Ultra Turrax T8 at full speed for $1.5 \mathrm{~min}$. Immediately, $10 \mu \mathrm{L}$ sample was taken from the bottom and diluted (1: 100) with a $0.1 \%$ SDS solution. The absorbance was measured at $500 \mathrm{~nm}$ in a Synergy ${ }^{\mathrm{TM}} \mathrm{HTX}$ multi-mode microplate reader spectrophotometer (BioTek, USA) with the SDS solution as blank and using $200 \mu \mathrm{L}$ in each well of the microplate (96 wells). The EAI and ESI were calculated as follows:

$$
\operatorname{EAI}\left(\mathrm{m}^{2} / \mathrm{g}\right)=\frac{2(2.303) \cdot \mathrm{A}_{0} \cdot \mathrm{F}}{(1-\varphi) \cdot \mathrm{C} \cdot \mathrm{L}}
$$

$\operatorname{ESI}(\min )=\frac{\mathrm{A}_{0} \cdot \mathrm{t}}{\Delta \mathrm{A}}$

Where $\mathrm{F}$ is the dilution factor (100), $\phi$ is the volume fraction of oil $(0.25), \mathrm{C}$ is the weight of the protein per unit volume in the aqueous phase $\left(10,000 \mathrm{~g} / \mathrm{m}^{3}\right), \mathrm{L}$ is the path length of the well with the volume used $(0.00685 \mathrm{~m}), \mathrm{A}_{0}$ is the absorbance measured at $500 \mathrm{~nm}$ at $0 \mathrm{~min}, \mathrm{t}$ is the time ( $10 \mathrm{~min}$ ), and $\Delta \mathrm{A}$ is the absorbance difference between $0 \mathrm{~min}$ and 10 min to maintain the static emulsion.

\section{Foaming capacity (FC) and foaming stability (FS)}

The FC and FS were analyzed using the method of Zhu et al. [31] with modification, for which a 1\% GPPPC and 1\% MPPPC solution were prepared, and the $\mathrm{pH}$ was adjusted to $\mathrm{pH} 7$ and stirred for $1 \mathrm{~h}$ at room temperature. The solution was homogenized with an Ultra Turrax T8 at full speed for $1 \mathrm{~min}$. After, 0,30 and 60 minutes, the volume of the samples was measured and recorded. $\mathrm{FC}$ was expressed as foam expansion by volume difference before and after whipping. FS was calculated as the volume of foam remaining after 30 and $60 \mathrm{~min}$. FC and FS were calculated using the following formula:

$$
\begin{aligned}
& \mathrm{FC}(\%)=\frac{\mathrm{V}_{\mathrm{t}}-\mathrm{V}_{0}}{\mathrm{~V}_{0}} \times 100 \\
& \mathrm{FS}(\%)=\frac{\mathrm{FC}}{\mathrm{FC}_{0}} \times 100
\end{aligned}
$$

Where $V_{0}$ is the initial volume before whipping, $V_{t}$ is the total volume after different times, and $\mathrm{FC}_{0}$ is the $\mathrm{FC}$ at $0 \mathrm{~min}$.

\section{Statistical analysis}

All determinations were carried out in triplicate, and the results are expressed as mean \pm SD. Analysis of variance was performed using the Start Graphic Software followed by the Duncan's test intergroup comparison tests. The level of significance was defined at $p<0.05$. 


\section{RESULTS}

PPPC was obtained of GPPPC and MPPPC from C. cajan (Fig. 1).

GPPPC and MPPPC were isolated by alkaline extraction at $\mathrm{pH} 8.5$ and $\mathrm{pH} 12.5$ followed by isoelectric precipitation at $\mathrm{pH} 4.5$ using water as solvent. GPPPC presents a protein content of $63.92 \%$ of total content and MPPPC presents a percentage of $76.41 \%$ of protein, a higher value than GPPPC. Protein content of GPPPC and MPPPC was determined using the Dumas method. GPPPC presents a high value of moisture with $11.76 \%$ compared to MPPPC with a value of $6.46 \%$, while the ash content was higher in GPPPC with a value of $13.44 \%$ (Table 1).

\section{SDS-PAGE electrophoresis analysis of GPPPC and MPPPC}

Fig. 2 shows the protein profile present in GPPPC and MPPPC. GPPPC profile showed polypeptides of MW between $37 \mathrm{kDa}$ and $75 \mathrm{KDa}$, the band most intensive was observed with a MW of $50 \mathrm{Kda}$, and this band corresponds to vicilin (7S globulin) protein from pigeon pea. MPPPC profile has subunits of polypeptides between $10 \mathrm{kDa}$ and $75 \mathrm{kDa}$, and MPPPC presents a protein profile more complex with more intensive bands. The bands with most intensity were the bands with MW of $50 \mathrm{kDa}$ and $70 \mathrm{kDa}$. Bands of $50 \mathrm{kD}$ and $70 \mathrm{kDa}$ correspond to vicilin protein from pigeon pea. Bands of $25 \mathrm{kDa}$ and $35 \mathrm{kDa}$ can be $11 \mathrm{~S}$ globulins.

\section{Characterization of GPPPC and MPPPC by RP-UHPLC analysis}

GPPPC and MPPPC also were analyzed by the RP-UHPLC method at a wavelength of $280 \mathrm{~nm}$. GPPPC presents four main fractions, namely, F1, F2, F3, and F4. F1 presents high intensity in the chromatogram near 200 AU. F2, F3, and F4 fractions present low intensity in the GPPPC chromatogram. F1 is very hydrophilic with polar charge as their

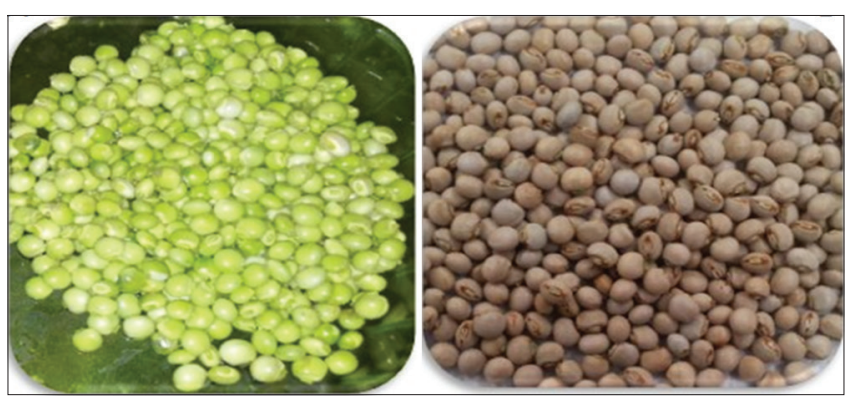

Fig. 1: (a) Green seeds of pigeon pea (Cajanus cajan) and (b) mature seeds of pigeon pea (Cajanus cajan)

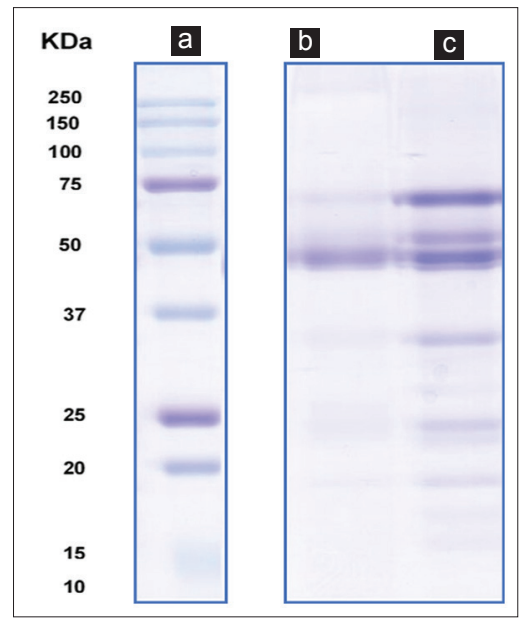

Fig. 2: Sodium dodecyl sulfate polyacrylamide gel electrophoresis analysis of Pigeon protein concentrate of green seeds and Pigeon protein concentrate of mature seeds from seeds of Cajanus cajan. (a) Standard marker, (b) GPPPC, and (c) MPPPC retention time is the start run of elution. $\mathrm{F} 4>\mathrm{F} 3>\mathrm{F} 2$ in hydrophobicity capacity (Fig. 3).

MPPPC presents the same profile of peaks in the chromatogram of analysis with four fractions, with the same retention time, namely, F1, F2, F3, and F4. MPPPC F1 presents higher intensity than GPPPC F1, with $550 \mathrm{AU}$ of intensive. When the MPPPC chromatogram is in the same scale as the GPPPC chromatogram, we can observe the same fractions profile. MPPPC F1 intensity indicates that this sample can have a higher protein content (Fig. 4). This result is in accordance with the protein content determined by the Dumas method and the SDS-PAGE electrophoresis technique.

\section{Functional properties of GPPPC and MPPPC Protein solubility (PS)}

PS is probably one of the most important functional properties of proteins molecules, as a high solubility allows many industrial uses, while low solubility decreases the industrial possibilities. Solubility capacity affects other protein functional properties.

The MPPPC protein solubility profile presents the typical U-shape of the legume extracts, with a minimum solubility at the isoelectric point and a greater solubility at low acidic $\mathrm{pH}$ and high alkaline $\mathrm{pH}$ (Singh et al., 1980). GPPPC solubility profile has not the characteristic U-shape graphic (Fig. 5). At pH 2.0, the MPPPC solubility was $58.43 \pm 0.11 \%$ and GPPPC presents $17.95 \pm 0.41 \%$, which indicates a high hydrophobicity of

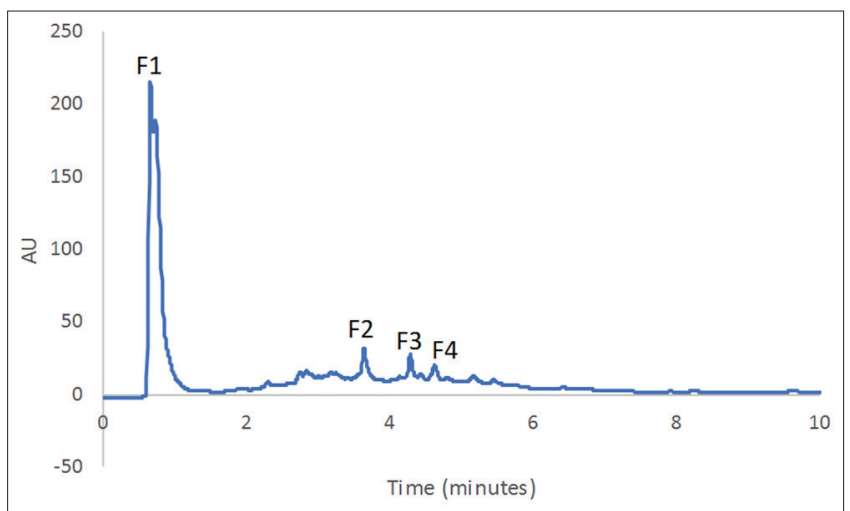

Fig. 3: Reverse-phase ultra-performance liquid chromatography analysis of Pigeon protein concentrate of green seeds from seeds (Cajanus cajan) at $280 \mathrm{~nm}$

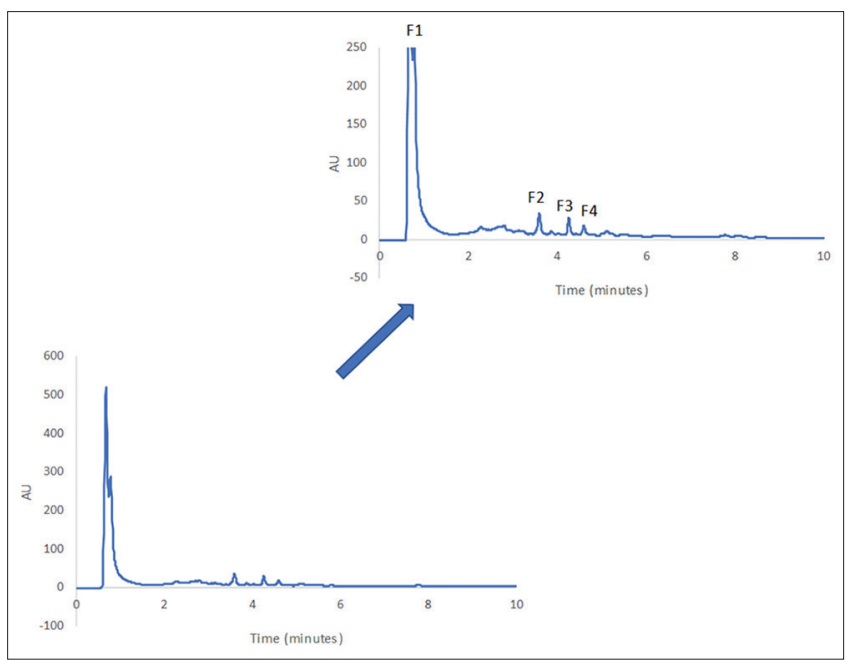

Fig. 4: Reverse-phase ultra-performance liquid chromatography analysis of Pigeon protein concentrate of mature seeds from seeds (Cajanus cajan) at $280 \mathrm{~nm}$ 
GPPPC at low $\mathrm{pH}$ values. At $\mathrm{pH} 4.0$, the solubility decreases with values of $3.29 \pm 0.39 \%$ and $6.98 \pm 0.25 \%$ for MPPPC and GPPPC, respectively. This $\mathrm{pH}$ is near to the isoelectric point of proteins from pigeon pea.

GPPPC and MPPPC solubility capacity increases progressively when $\mathrm{pH}$ increases. GPPPC increases their solubility faster at $\mathrm{pH} 6.0$ with respect to MPPPC, being $35.32 \pm 1.84 \%$ and $11.45 \pm 0.22 \%$, respectively. At $\mathrm{pH} 7.0$, GPPPC and MPPPC have a similar percentage of solubility capacity. At pH 12.0, MPPPC presents higher solubility with a value of $62.77 \pm 0.35 \%$ and GPPPC presents a value of $59 \pm 2.12 \%$ of solubility capacity.

\section{WAC}

GPPPC presents higher WAC with a value of $5.35 \%$ of WAC and MPPPC presents a value of $2.0 \%$ of WAC (Table 2), and these values were statistically different at $\mathrm{p}<0.05$.

OAC

GPPPC has a lower OAC than MPPPC (Table 2) with value of $1.89 \%$ and $3.12 \%$ of OAC, respectivelly. These value were statistically different at $\mathrm{p}<0.05$.

\section{EAI}

GPPPC presents $3.95 \%$ of EAI and MPPPC presents $3.18 \%$ of EAI. These results were significantly different $(\mathrm{p}<0.05)$ (Table 2$)$.

\section{ESI}

GPPPC presents a value of $16.22 \%$ of ESI and MPPPC presents a value of $40.15 \%$ of ESI. MPPPC presents the higher ESI with a totally different

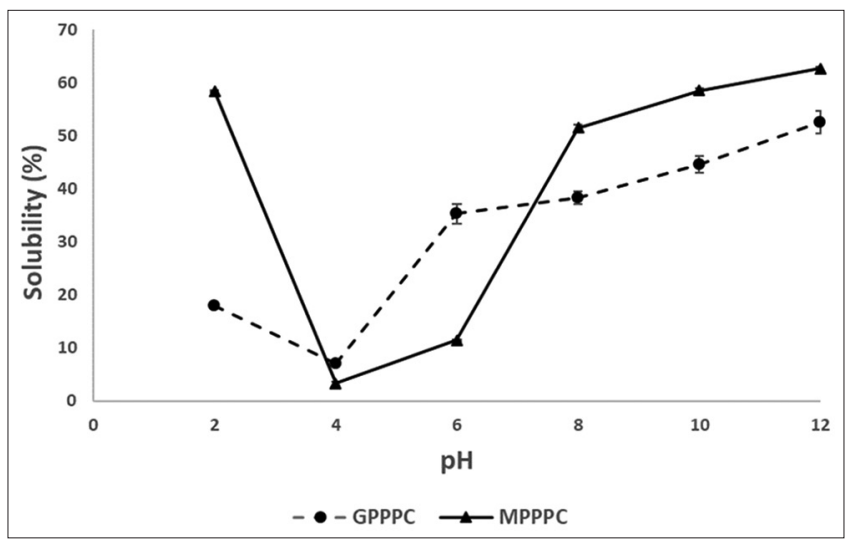

Fig. 5: Effect of $\mathrm{pH}$ on the solubility of Pigeon protein concentrate of green seeds from seeds and Pigeon protein concentrate of mature seeds

Table 1: Content of CP, moisture, and ash of GPPPC and MPPPC

\begin{tabular}{llll}
\hline PC & CP (\%)* & Moisture (\%)* & Ash (\%)* \\
\hline GPPPC & $63.92 \pm 0.42^{\mathrm{a}}$ & $11.76 \pm 0.05^{\mathrm{a}}$ & $13.44 \pm 0.20^{\mathrm{a}}$ \\
MPPPC & $76.41 \pm 1.76^{\mathrm{b}}$ & $6.46 \pm 0.49^{\mathrm{b}}$ & $8.90 \pm 0.67^{\mathrm{b}}$ \\
\hline
\end{tabular}

Values are mean $\pm S D(n=3)$. The values followed by different letters in the same column are significantly different $(p<0.05) .{ }^{*}$ Percentage on dry weight basis. CP: Crude protein, GPPPC: Pigeon protein concentrate of green seeds, MPPPC: Pigeon protein concentrate of mature seeds, PC: Protein concentrate
ESI value in GPPPC (Table 2). These values were statistically different at $p<0.05$.

FC

GPPPC presents a FC percentage $27.30 \%$ and MPPPC presents a higher value of $68.50 \%$ of FC. These results were different significantly $(\mathrm{p}<0.05)$ (Table 2).

FS

GPPPC and MPPPC FS was determined at 5, 30, and 60 min of incubation. The percentage of FS of GPPPC and MPPPC decreases with the increase of the time $5 \mathrm{~min}>30 \mathrm{~min}>60 \mathrm{~min}$. At $5 \mathrm{~min}$, GPPPC and MPPPC present the highest values with a value of $71.15 \%$ and $96.03 \%$ of FS, respectively. At $30 \mathrm{~min}$, GPPPC presents a FS value of $56.73 \%$ and MPPPC presents a FS value of $81.99 \%$. At $60 \mathrm{~min}$, GPPPC presents a FS value of $27.88 \%$ and MPPPC presents a FS value of $66.02 \%$.

\section{DISCUSSION}

Storage proteins include the protein content in seeds of plant species. Storage proteins have been classified in four groups: Globulins, glutelins, albumins, and prolamins depending on their solubility in different solvents (water, salts, and alcohols). Storage proteins include few protein classes, one of which is the globulin class [32]. Based on the sedimentation coefficients, legume globulins can be divided in two groups: The $7 \mathrm{~S}$ vicilin globulins type and the $11 \mathrm{~S}$ legumin-like globulins, these globulins differ in their physical and chemical properties. The $7 \mathrm{~S}$ globulin class is named vicilins and the $11 \mathrm{~S}$ globulin class is named legumins [33]. Depending on the source, both are designed with specific names, i.e., phaseolin in Phaseolus, conglycinin in glycine, and canavalin in Canavalia (vicilins) and glycinin in glycine (legumin) [34]. Protein content of pigeon pea seeds can be from $22 \%$ to $28 \%$ of protein on a dry basis. In pigeon pea, globulin proteins represent around $54-60 \%$ of globulins of the total protein content, albumins with a value of $10-15 \%$ of total protein content, glutelin fraction with a percentage of $10-15 \%$ of glutelins of total protein content, and prolamins having around $4-5 \%$ of total protein content [35]. Krishnan et al. 2017 reported a proteins profile of pigeon pea (Cajanus cajan) using the SDS-PAGE electrophoresis. They found profile proteins with bands between $10 \mathrm{kDa}$ and $100 \mathrm{kDa}$. The most abundant proteins of pigeon pea had MWs of $64 \mathrm{kDa}$ and $47 \mathrm{kDa}$. These two prominent proteins represent the two subunits of the 7S vicilin. The $11 \mathrm{~S}$ legumin-like proteins are not abundant in pigeon pea total seed protein [36]. In this study, in GPPPC, a band of $50 \mathrm{kDa}$ was identified being a vicilin type globulin. In MPPPC, bands of MW of $50 \mathrm{kDa}$ and $70 \mathrm{kDa}$ were identified as a vicilin-type globulin. Our values are in accordance with the ones reported by Krishnan et al., 2017, with MWs near to the ones reported in this study [36].

Mwasaru et al. [37] have reported MPPPC solubility capacity in pigeon pea seeds, obtained at $\mathrm{pH} 2.0$ and $\mathrm{pH} 12.0$ and an isoelectric precipitation at $\mathrm{pH}$ 4.5. The profile of MPPPC solubility was similar to the one reported in this study. For example, at pH 2.0 and pH 12.0, both PPPCs present the same percentage of solubility. Only at $\mathrm{pH} 7.0$ and $\mathrm{pH}$ 8.0, small differences are reported.

Toews and Wang [6] reported WAC of chickpea (variety B90) and the commercial PI of pea with values of $2.3 \mathrm{~g} / \mathrm{g}$ and $2.1 \mathrm{~g} / \mathrm{g}$, respectively. In this study, a value of $2.0 \mathrm{~g} / \mathrm{g}$ to MPPPC was reported. GPPPC presents a higher value with $5.35 \mathrm{~g} / \mathrm{g}$.

Table 2: Functional properties of GPPPC and MPPPC: Percentage of WAC, OAC, ESI, and FC

\begin{tabular}{|c|c|c|c|c|c|c|c|c|}
\hline \multirow[t]{2}{*}{ Sample } & \multirow[t]{2}{*}{ WAC $(g / g)$} & \multirow[t]{2}{*}{ OAC (g/g) } & \multirow[t]{2}{*}{ EAI $\left(m^{2} / g\right)$} & \multirow[t]{2}{*}{ ESI (min) } & \multirow[t]{2}{*}{ FC (\%) } & \multicolumn{3}{|l|}{ FS (\%) } \\
\hline & & & & & & $5 \mathrm{~min}$ & $30 \mathrm{~min}$ & $60 \mathrm{~min}$ \\
\hline GPPPC & $5.35 \pm 0.26^{\mathrm{a}}$ & $1.89 \pm 0.03^{\mathrm{a}}$ & $3.95 \pm 0.97^{\mathrm{a}}$ & $16.22 \pm 0.33^{\mathrm{a}}$ & $27.30 \pm 0.61^{\mathrm{a}}$ & $71.15 \pm 1.85^{\mathrm{a}}$ & $56.73 \pm 1.72^{\mathrm{a}}$ & $27.88 \pm 1.59^{a}$ \\
\hline МPPPC & $2.00 \pm 0.21^{\mathrm{b}}$ & $3.12 \pm 0.06^{b}$ & $3.18 \pm 0.02^{b}$ & $40.15 \pm 0.47^{b}$ & $68.50 \pm 2.13^{b}$ & $96.03 \pm 2.25^{\mathrm{b}}$ & $81.99 \pm 3.05^{\mathrm{b}}$ & $66.02 \pm 1.55^{b}$ \\
\hline
\end{tabular}

Values are mean $\pm \mathrm{SD}(\mathrm{n}=3)$. The values followed by different letters in the same column are significantly different $(\mathrm{P}<0.05)$, WAC: Water absorption capacity, OAC: Oil absorption capacity, ESI: Emulsion stability index, FC: Foaming capacity, SD: Standard deviation, GPPPC: Pigeon protein concentrate of green seeds, MPPPC: Pigeon protein concentrate of mature seeds, PC: Protein concentrate 
MPPPC presents an OAC value higher when is compared to other legumes PC, such as pea, lentil, navy bean, chickpea, and commercial PI of soybean and pea. On the other hand, GPPPC presents an OAC value of $(1.8 \mathrm{~g} / \mathrm{g})$ like the PC values. Fernández-Quintela et al. [38] reported PI of pea, faba bean, and soybean with OACs of $1.2 \mathrm{~g} / \mathrm{g}, 1.6 \mathrm{~g} / \mathrm{g}$, and $1.1 \mathrm{~g} / \mathrm{g}$, respectively. MPPPC presents an OAC value of $3.12 \mathrm{~g} / \mathrm{g}$. This value was higher than the value reported in this study.

GPPPC presents EAI of $3.95 \mathrm{~m} 2 / \mathrm{g}$ and MPPPC presents EAI of $3.18 \mathrm{~m}^{2} / \mathrm{g}$. These values were low compared to the EAI values of other proteins concentrates, such as kidney bean $\left(21.3 \mathrm{~m}^{2} / \mathrm{g}\right.$ and $23.7 \mathrm{~m}^{2} / \mathrm{g}$ of EAI), field pea $\left(13.1 \mathrm{~m}^{2} / \mathrm{g}\right.$ of EAI), and soy PI (12.2 $\mathrm{m}^{2} / \mathrm{g}$ of EAI).

In this study, GPPPC presents 16.22 min ESI and MPPPC presents 40.15 min ESI. Shevkani et al. [39] reported ESI values of kidney bean and field pea of $46.0 \mathrm{~min}$ and $78.1 \mathrm{~min}$, respectively, GPPPC (16.22 $\mathrm{min}$ ), and MPPPC (40.15 min) present a low value. Achouri et al. 2012 reported a value of $16.8 \mathrm{~min}$ (ESI) for soy PI. The value reported in this study for MPPPC was high compared to the soy PI value ESI [40].

In this study, GPPPC presents $27.30 \%$ of FC and MPPPC presents a value of $68.50 \%$ of FC. Akintayo et al. [41] described MPPPC obtained by alkaline extraction at $\mathrm{pH} 8.5$ with $80 \%$ of $\mathrm{FC}$, with $72 \%$ of protein content. MPPPC presents an FC similar value of PPPI obtained by alkaline extraction at $\mathrm{pH} 9.5$ (68 $\pm 3.09 \%$ of $\mathrm{FC})$ reported by Butt and Batool [5].

Green and mature pigeon pea PC differ significantly in terms of functional properties. The differences found in both PC are derived from the changes suffered by the proteins in the different stages of development, such as changes in concentration, composition, structure, charges, and hydrophobicity, which have been revealed in previous studies, and reflected in the variation of the functional properties of GPPPC and MPPPC. GPPPC presents higher in WAC and EAI, while MPPPC is higher in OAC, ESI, FC, and FS. Thus, MPPPC is more suitable for cold meat products, sauces, beverages, ice creams, and whipped creams, while GPPPC is more suitable in bakery products; considering that, the solubility of the protein in GPPPC showed that it is unsuitable for products of high acidity due to its deficient solubility at low $\mathrm{pH}$. These results support the use of pigeon pea proteins not only to increase protein levels but also as ingredients providing technological improvements in the generation of consumer products. The reproductive stage of seeds to obtain the protein extract to be used is important to be considered, depending on the technological property required in the specific food process.

\section{ACKNOWLEDGMENTS}

This study was supported by Project REDU: Valoración de la calidad nutricional y funcional de alimentos tradicionales de la población ecuatoriana. PI-REDU-2015-012. Pazminño A thanks, Laboartorio de Propiedades Físico-Químicas y Biológicas de los Alimentos. Ingeniería en Alimentos-FIMCP-ESPOL. Wilman Carrillo thanks, Universidad Técnica de Ambato, Ecuador (Project CPU-1373-2014-UTA) and (Project Canje de Deuda, España-Ecuador). This work has been reviewed in the English edition by Emilio Labrador.

\section{AUTHOR'S CONTRIBUTIONS}

Pazmiño A, Vásquez G, and Carrillo $\mathrm{W}$ conceived and designed the experiments. Carrillo $\mathrm{W}$ wrote the paper and sent for the reviewer in the journal AJPCR.

\section{CONFLICTS OF INTERESTS}

The authors declare no conflict of interest.

\section{REFERENCES}

1. Kilara A, Vaghela MN. Whey proteins. In: Proteins in Food Processing. $2^{\text {nd }}$ ed. Duxford, UK: Elsevier; 2018. p. 93-126.
2. Sui X, Bi S, Qi B, Wang Z, Zhang M, Li Y, et al. Impact of ultrasonic treatment on an emulsion system stabilized with soybean protein isolate and lecithin: Its emulsifying property and emulsion stability. Food Hydrocoll 2017:63:727-34.

3. Boye J, Zare F, Pletch A. Pulse proteins: Processing, characterization, functional properties and applications in food and feed. Food Res Int 2010;43:414-31.

4. González-Pérez S, Arellano JB. Vegetable protein isolates. In: Handbook of Hydrocolloids. Duxford, UK: Elsevier; 2009. p. 383-419.

5. Butt MS, Batool R. Nutritional and functional properties of some promising legumes protein isolates. Pak J Nutr 2010;9:373-9.

6. Toews R, Wang N. Physicochemical and functional properties of protein concentrates from pulses. Food Res Int 2013;52:445-51.

7. Carrillo W, Guzmán X, Vilcacundo E. Native and heated hydrolysates of milk proteins and their capacity to inhibit lipid peroxidation in the zebrafish larvae model. Foods 2017;6:81.

8. Carrillo W, Monteiro KM, Martínez-Maqueda D, Ramos M, Recio I, Carvalho JE. Antiulcerative activity of milk proteins hydrolysates. J Med Food 2018;21. DOI: 10.1089/jmf.2017.0087.

9. Kobayashi Y, Park JW. Biochemical and physical characterizations of fish protein isolate and surimi prepared from fresh and frozen whole fish. LWT Food Sci Technol 2017;77:200-7.

10. Moras B, Rey S, Vilarem G, Pontalier PY. Pressurized water extraction of isoflavones by experimental design from soybean flour and soybean protein isolate. Food Chem 2017;214:9-15.

11. Acosta C, Carpio C, Vilcacundo R, Carrillo W. Identification of proteins isolate from amaranth (Amaranthus caudatus) by sodium dodecyl sulfate-polyacrylamide gel electrophoresis with water and $\mathrm{NaCl} 0.1 \mathrm{~m}$ solvents. Asian J Pharm Clin Res 2016;9:331-3.

12. Toapanta A, Carpio C, Vilcacundo R, Carrillo, W. Analysis of protein isolate from quinoa (Chenopodium quinoa Willd). Asian J Pharm Clin Pharm 2016;9:332-4

13. Poveda T, Vilcacundo R, Carpio C, Carrillo W. Analysis of sesame proteins isolate (Sesamum indicum $\mathrm{L}$ ) with water and salt treatment. Asian J Pharm Clin Res 2016;9:404-7.

14. Quinteros MF, Vilcacundo R, Carpio C, Carrillo W. Isolaton of proteins of Sacha inchi (Plukenetia volubilis L.) in presence of water and salt. Asian J Pharm Clin Res 2016;9:193-6.

15. Lara D, Vilcacundo E, Carrillo C, Carpio C, Silva M, Alvarez M, et al. Obtention of protein concentrate and polyphenols from macadamia (Macadamia integrifolia) with aqueous extraction method. Asian J Pharm Clin Res 2017;10:138-42.

16. Saxena KB, Kumar RV, Sultan R. Quality nutrition through pigeonpea A review. Health 2010;2:1335-44.

17. Singh N, Jain N, Kumar R, Jain A, Singh NK, Rai V. A comparative method for protein extraction and 2-D gel electrophoresis from different tissues of Cajanus cajan. Front Plant Sci 2015;6:606.

18. Mueller M, Puttipa R, Janngeon K, Unger F, Viernstein H, Okonogi S. Bioactivities of the Thai medicinal and edible plants C. Cajan, M. Citrifolia and O. Americanum. Int J Pharm Pharm Sci 2015;7:237-40.

19. Banala M, Kagithoju S, Pamulaparthi A, Edara C, Nanna R. In vitro antibacterial activity of leaf, seed, root, pod and flower extracts of Cajanus cajan (1.) millsp. Int J Pharm Pharm Sci 2015;7:265-8.

20. Kesari P, Sharma A, Katiki M, Kumar P, Gurjar B, Tomar S, et al. Structural, functional and evolutionary aspects of seed globulins. Protein Peptide Lett 2017;24:267-77.

21. Akande KE, Abubakar MM, Adegbola TA, Bogoro SE, Doma UD. Chemical evaluation of the nutritive quality of Pigeon Pea Cajanus cajan L. Millsp. Int J Poultry Sci 2010;9:63-5.

22. Mwasaru MA, Muhammad K, Bakar J, Man YB. Effects of isolation technique and conditions on the extractability, physicochemical and functional properties of pigeonpea (Cajanus cajan) and cowpea (Vigna unguiculata) protein isolates. I. Physicochemical properties. Food Chem 1999;67:435-43.

23. Rodsamran P, Sothornvit R. Physicochemical and functional properties of protein concentrate from by-product of coconut processing. Food Chem 2018;241:364-71.

24. Association of Analytical Communities International. Official Methods of Analysis of AOAC. $17^{\text {th }}$ ed. Gaithersburg, MD, USA: AOAC International; 2000.

25. American Association for Clinical Chemistry. Approved Methods of the American Association of Cereal Chemists. $8^{\text {th }}$ ed., Vol. 54. St. Paul, MN, USA: American Association of Cereal Chemists; 2000. p. 21.

26. Jung S, Rickert DA, Deak NA, Aldin ED, Recknor J, Johnson LA, Murphy PA. Comparison of kjeldahl and dumas methods for determining protein contents of soybean products. J Am Oil Chem Soc 2003;80:1169-73. 
27. Vilcacundo R, Miralles B, Carrillo W, Hernández-Ledesma B. In vitro chemopreventive properties of peptides released from quinoa (Chenopodium quinoa Willd.) protein under simulated gastrointestinal digestion. Food Res Int 2018;105:403-11.

28. Vilcacundo R, Barrio D, Carpio C, García-Ruiz A, Rúales J, HernándezLedesma B, et al. Digestibility of Quinoa (Chenopodium quinoa Willd.) protein concentrate and its potential to inhibit lipid peroxidation in the zebrafish larvae model. Plant Foods Hum Nutr 2017;72:294-300.

29. Jarpa-parra M, Bamdad F, Wang Y, Tian Z, Temelli F, Han J, et al. Optimization of lentil protein extraction and the in fluence of process $\mathrm{pH}$ on protein structure and functionality. LWT Food Sci Technol 2014;57:461-9.

30. Pearce KN, Kinsella JE. Emulsifying properties of proteins: Evaluation of a turbidimetric technique. J Agric Food Chem 1978;26:716-23.

31. Zhu K, Sun X, Chen Z, Peng W, Qian H, Zhou H. Comparison of functional properties and secondary structures of defatted wheat germ proteins separated by reverse micelles and alkaline extraction and isoelectric precipitation. Food Chem 2010;123:1163-9.

32. Shewry PR, Napier JA, Tatham AS. Seed storage proteins: Structures and biosynthesis. Plant Cell 1995;7:945-56.

33. Krishna TG, Bhatia CR. Vicilin from Cajanus cajan seeds. Phytochem 1985;24:2201-3.

34. Carbonaro M, Maselli P, Nucara A. Structural aspects of legume proteins and nutraceutical properties. Food Res Int 2015;76:19-30
35. Saxena KB, Sawargaonkar SL. Genetic enhancement of seed proteins in Pigeon pea methodologies, accomplishments, and opportunities. Int J Sci Res 2015;4:3-7.

36. Krishnan HB, Natarajan SS, Oehrle NW, Garrett WM, Darwish O. Proteomic analysis of Pigeon pea (Cajanus cajan) seeds reveals the accumulation of numerous stress-related proteins. J Agric Food Chem 2017;65:4572-81.

37. Mwasaru MA, Muhammad K, Bakar J, Man YB. Influence of altered solvent environment on the functionality of pigeon pea (Cajanus cajan) and cowpea (Vigna unguiculata) protein isolates. Food Chem 2000;7:157-65.

38. Fernández-Quintela A, Macarulla MT, del Barrio AS, Martinez JA. Composition and functional properties of protein isolates obtained from commercial legumes grown in northern Spain. Plant Foods Hum Nutr 1997;51:331-42.

39. Shevkani K, Singh N, Kaur A, Rana JC. Structural and functional characterization of kidney bean and field pea protein isolates: A comparative study. Food Hydrocoll 2015;43:679-89.

40. Achouri A, Nail V, Boye JI. Sesame protein isolate: Fractionation, secondary structure and functional properties. Food Res Int 2012;46:360-9.

41. Akintayo ET, Oshodi AA, Esuoso KO. Effects of $\mathrm{NaCl}$, ionic strength and $\mathrm{pH}$ on the foaming and gelation of pigeon pea (Cajanus cajan) protein concentrates. Food Chem 1999;66:51-6. 